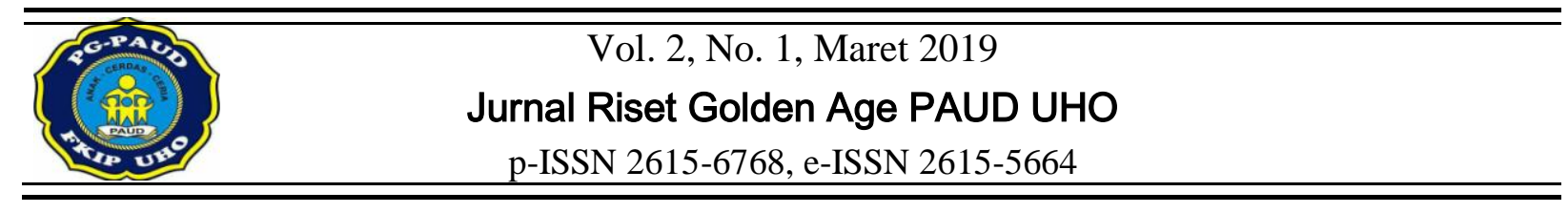

\title{
MENINGKATKAN KEMAMPUAN BERBAHASA ANAK MELALUI METODE BERCERITA
}

\author{
Ayunita Saribu ${ }^{1)}$, Afifah Nur Hidayah ${ }^{1)}$ \\ ${ }^{1}$ Jurusan PG-PAUD, Universitas Halu Oleo. Jln. H.E.A Mokodompit, Kendari 93232, Indonesia.
}

\begin{abstract}
Abstrak
Penelitian ini bertujuan untuk meningkatkan kemampuan berbahasa anak melalui metode bercerita di kelompok B TK Mekar Indah Kendari. Subjek dalam penelitian ini adalah guru dan anak didik di Kelompok B TK Mekar Indah Kendari yang berjumlah 16 anak didik yang terdiri atas 8 orang anak laki-laki dan 8 orang anak perempuan. Jenis penelitian ini adalah Penelitian Tindakan Kelas yang dilaksanakan dalam dua siklus. Tahap-tahap dalam penelitian tindakan kelas ini, yaitu: (1) perencanaan, (2) pelaksanaan tindakan, (3) pengamatan, dan (4) refleksi.Berdasarkan analisis data hasil observasi aktivitas mengajar guru pada siklus I diperoleh presentase ketercapaian sebesar 73\%, kemudian mengalami peningkatan pada siklus II sebesar 91\%. Aktivitas belajar anak pada siklus I diperoleh presentase ketercapaian sebesar $64 \%$, kemudian mengalami peningkatan pada siklus II sebesar $82 \%$. Sedangkan hasil belajar anak menunjukkan adanya peningkatan. Hal ini dapat dibuktikan pada hasil observasi awal sebelum tindakan dan sesudah tindakan. Sebelum tindakan diperoleh presentase sebesar $31 \%$. Pada siklus I diperoleh presentase sebesar 56\%, kemudian mengalami peningkatan pada siklus II sebesar $88 \%$. Dengan demikian dapat disimpulkan bahwa kemampuan berbahasa anak dapat ditingkatkan melalui metode bercerita di kelompok B TK Mekar Indah Kendari.
\end{abstract}

Kata Kunci : Kemampuan Berbahasa, Metode Bercerita, Anak.

\section{THE IMPROVING OF CHILDREN LANGUAGE SKILLS ABILITY THROUGH STORYTELLING METHOD}

\begin{abstract}
This study aims to improving of children language skills ability through storytelling method in group B TK Mekar Indah Kendari. The subjects in this study were teachers as researchers and child in group B TK Mekar Indah Kendari which totalling 16 children, consist of 8 girls and 8 boys. This research is a classroom action research. The types of the research was classroom action research, that's conducted by two cycles. Each cycle consist of: (1) planning, (2) action, (3) observation and evaluation, (4) reflection. Based on the result of data analysis in teaching teachers activities obtained the percentage to achievement of $73 \%$, then increased in the second cycle of $91 \%$. Student learning activities in the first cycle obtained the percentage to achievement of $64 \%$, then increased in the second cycle of $82 \%$. While the results show an increased in children's learning activity. This is provethat the results of pre-observations before the procedure and after the action. Before the action was obtained for $31 \%$.. In thefirst cycle obtained a percentage of 56, then increased in the second cycle of $88 \%$ completeness. It can be concluded that language skills can be enhanced through storytelling in group B TK Mekar Indah Kendari.
\end{abstract}

Keyword: Language Skills Ability, Storytelling Method, Child.

\section{PENDAHULUAN}

Menurut Undang-Undang Nomor 20 Tahun 2003 tentang Sistem Pendidikan Nasional pasal 1 ayat 14 disebutkan bahwa pendidikan anak usia dini adalah suatu upaya pembinaan yang ditujukan kepada anak sejak lahir sampai usia enam tahun, yang dilakukan melalui pemberian rangsangan pendidikan untuk membantu pertumbuhan dan perkembangan jasmani dan rohani, agar anak memiliki kesiapan dalam memasuki pendidikan lebih lanjut (Dikdasmen, 2010 : 1). 
Pendidikan anak usia dini merupakan upaya pembinaan yang ditujukan kepada anak sejak lahir sampai dengan usia enam tahun yang dilakukan melalui pemberian stimulus pendidikan agar membantu perkembangan, pertumbuhan baik jasmani maupun rohani sehingga anak memiliki kesiapan memasuki pendidikan yang lebih lanjut. Keseriusan pemerintah terhadap pentingnya pendidikan anak usia dini berdampak pada tingginya kesadaran dan partisipasi dan kebutuhan masyarakat terhadap pentingnya pendidikan anak usia dini dalam menghasilkan sumber daya manusia yang berkualitas yang tercantum dalam Pasal 1 ayat (1) Undang-undang Nomor 20 Tahun 2003, Martinis Yamin \& Jamilah Sabri Sanan (2013: 4) tentang Sistem Pendidikan Nasional.

Pendidikan anak usia dini menitikberatkan pada aspek perkembangan fisik motorik, kognitif, bahasa, sosial emosional, serta nilai agama dan moral. Semua aspek tersebut harus distimulasi secara menyeluruh agar anak memiliki berbagai potensi yang harus dioptimalkan.

Nurbiana Dhieni (2005: 1.1) bahasa adalah salah satu faktor mendasar yang membedakan manusia dengan hewan. Bahasa sebagai anugrah dari Sang Pencipta memungkinkan individu dapat hidup bersama dengan orang lain, membantu memecahkan masalah, dan memposisikan dirinya sebagai makhluk yang berbudaya. Bahasa merupakan alat untuk berkomunikasi. Melalui bahasa manusia berinteraksi dan berkomunikasi mengemukakan hasil pemikirannya dan dapat mengekspresikan perasaannya. Anak-anak belajar bahasa melalui interaksi dengan lingkungannya baik lingkungan rumah, sekolah, atau masyarakat.

Badudu dalam Nurbiana Dhieni (2005: 1.11) bahasa merupakan alat penghubung atau komunikasi antar masyarakat, yang terdiri dari individu-individu yang menyatakan perasaan, dan keinginannya. Bahasa sebagai sistem lambang bekerjasama, berinteraksi, dan mengidentifikasi diri. Bromley (1992) dalam Nurbiana Dhieni (2005: 1.11) mendefinisikan bahasa sebagai simbol yang teratur untuk mentransfer berbagai ide maupun informasi yang terdiri dari simbol-simbol visual maupun verbal. Simbol-simbol visual tersebut dapat dilihat, ditulis dan dibaca, sedangkan simbolsimbol verbal dapat diucapkan dan didengar.
Bahasa sebagai fungsi dari komunikasi memungkinkan dua individu atau lebih mengekspresikan berbagai ide, arti, perasaan dan pengalaman. Menurut Badudu (1989) dalam Nurbiana Dhieni (2005: 1.11) menyatakan bahwa bahasa adalah alat penghubung atau komunikasi antara anggota masyarakat yang terdiri dari individu-individu yang menyatakan pikiran, perasaan dan keinginannya. Kemampuan bahasa dipelajari dan diperoleh anak usia dini secara alamiah untuk beradaptasi dengan lingkungannya.

Pada aspek perkembangan bahasa, kompetensi dan hasil yang diharapkan adalah anak mampu menggunakan bahasa sebagai pemahaman bahasa pasif dan dapat berkomunikasi secara efektif yang bermanfaat untuk berpikir dan belajar dengan baik. Martinis Yamin (2012: 103). Perkembangan bahasa anak tidak saja dipengaruhi oleh perkembangan neurologis tetapi juga oleh perkembangan biologisnya. Pertumbuhan biologis ini akan tampak pula dalam konstruksi fisik mulut seorang anak. Pada saat seorang anak dilahirkan, fisiologi mulutnya masih sangat terbatas dimana laringnya masih tinggi, lidahnya relatif besar, daerah gerak di mulut sangat sempit, dan lidahnya masih bersandar pada belakang bibirnya.

Ecka Pramita (2010: 45-46) kemampuan bahasa ialah kemampuan anak untuk mendengar dan menjalankan perintah serta bercerita. Pada usia 4 tahun, anak mulai dapat merangkai kata lebih banyak lagi. Di usia ini ada sekitar 1.000 sampai 1.500 kata yang sudah dapat diucapkannya. Seiring dengan pertumbuhannya, kata yang dimilikinya akan terus bertambah. Salah satu bentuk kalimat umum yang paling sering digunakan anak-anak adalah kalimat bertanya. Ini sejalan dengan tahapan perkembangan kognitifnya yang selalu ingin tahu tentang segala hal. Itu sebabnya, mereka cenderung "ceriwis" karena banyak bertanya dan koleksi kata-katanya pun semakin banyak. Kadang-kadang kata yang diucapkannya masih terdengar lucu. Hingga banyak orang tua sangat suka mendengar perkataan-perkataan mereka. Topik pembicaraan yang mereka lakukan, umumnya berpusat pada dirinya. Mereka terutama berbicara tentang dirinya sendiri, pengalamannya bergaul dengan teman sebaya dan hubungan mereka dengan anggota keluarga lain. Kadang-kadang, omongan anak sering meniru gaya bahasa orang dewasa. Namun dalam bentuk yang belum sempurna seperti 
mengomentari sesuatu hal atau masalah rutin sehari-hari.

Secara umum, perkembangan keterampilan berbahasa pada individu menurut Berk 1989 dalam Ngalimun (2013: 35) dapat dibagi ke dalam empat komponen yaitu: 1) Fonologi (phonology), 2) Semantik (semantics), 3) Tata bahasa (grammar), 4) Pragmatik (pragmatics).

Dari beberapa pendapat para ahli diatas dapat disimpulkan bahwa kemampuan berbahasa merupakan berinteraksi dan berkomunikasi mengemukakan hasil pemikirannya dan dapat mengekspresikan perasaannya.

Perkembangan berpikir anak usia taman kanak-kanak berkembang sangat pesat. Dalam masa-masa ini segala potensi kemampuan anak dapat dikembangkan secara optimal termaksud kemampuan berbahasa. Tentunya dari bantuan orang-orang yang berada di lingkungan anakanak tersebut. Namun kenyataannya Perkembangan bahasa di TK Mekar Indah Kendari masih sangat rendah. Dari hasil observasi awal yang saya lakukan (wawancara dengan Ibu Mihrah, S.Pd pada hari Sabtu, 27 Agustus 2016), 69\% anak-anak masih pasif dalam kegiatan bercakap-cakap.

Bercerita adalah suatu kegiatan yang dilakukan seseorang secara lisan kepada orang lain dengan alat atau tanpa alat tentang apa yang harus disampaikan dalam bentuk pesan, informasi, atau hanya sebuah dongeng yang untuk didengar dengan rasa menyenangkan. Gordon dan Browne dalam Moeslichatoen (2004: 26) menyatakan bahwa bercerita merupakan cara untuk meneruskan warisan budaya dari suatu generasi ke generasi berikutnya. Moeslichatoen (2004: 26) menyatakan bahwa bercerita mempunyai makna penting bagi perkembangan anak TK karena melalui bercerita.

Mansyur (2007: 41) metode bercerita sangat penting diterapkan pada anak usia dini. Tidak salah bila metode bercerita ini sebisa mungkin diaplikasikan dalam pembelajaran. Selain untuk memudahkan anak dalam memahami materi yang diberikan, juga untuk memberikan daya imajinatif dan fantasi, serta menambahkan wawasannya terhadap nilai-nilai kebaikan. Bila isi cerita dikaitkan dengan dunia kehidupan anak maka mereka dapat memahami isi cerita itu, mereka akan mendengarkan dengan penuh perhatian, dan dengan mudah dapat menangkap isi cerita. Dunia kehidupan anak penuh suka cita, maka kegiatan bercerita harus diusahakan dapat memberikan perasaan gembira, lucu dan mengasyikkan.

Bachri Bachtiar (2005: 10) bercerita adalah menuturkan sesuatu yang mengisahkan tentang perbuatan atau sesuatu kejadian dan disampaikan secara lisan dengan tujuan membagikan pengalaman dan pengetahuan kepada orang lain. Nurbiana Dhieni (2005 : 6.35) ada beberapa langkah penerapan metode bercerita yaitu : a. Anak mengatur posisi duduknya, b. Anak memperhatikan guru menyiapkan alat peraga, c. Anak termotivasi untuk mendengarkan cerita, d. Anak diberi kesempatan untuk memberi judul cerita, e. Anak mendengarkan judul cerita dan anak mendengarkan cerita guru sambil memperhatikan gambar yang guru perlihatkan.

Pada prinsipnya manfaat metode bercerita menurut Nurbiana Dhieni (2005: 6.8) adalah: a. Melatih daya serap atau daya tangkap anak TK, b. Melatih daya pikir anak TK untuk terlatih memahami proses cerita, c. Melatih daya konsentrasi anak TK, d. Mengembangkan daya imajinasi anak, e. Menciptakan senang mendengarkan cerita, e. Membantu perkembangan bahasa anak dalam berkomunikasi secara efektif dan efisien.

Dari beberapa pendapat para ahli diatas dapat disimpulkan bahwa bercerita merupakan suatu kegiatan secara lisan untuk mengisahkan sesuatu kepada orang lain dengan tujuan berbagi pengalaman.

\section{METODE}

Jenis penelitian yang digunakan dalam penelitian ini adalah Penelitian Tindakan Kelas (PTK). Arikunto (2010: 135) menyatakan bahwa penelitian tindakan kelas (classroom action research) adalah penelitian yang dilakukan oleh guru ke kelas atau di sekolah tempat iamengajar dengan penekanan pada penyempurnaan atau peningkatan proses dan praksis pembelajaran.

Penelitian ini di laksanakan di TK Mekar Indah Kendari, Jalan Mekar Sulawesi Tenggara. Penelitian ini akan dilaksanakan pada semester I tahun ajaran 2016/2017, bulan September 2016.

Subjek dalam penelitian ini adalah guru kelompok B TK Mekar Indah Kendari (ibu Mihrah, S.Pd) dan anak didik kelompok B TK Mekar Indah Kendari yang berjumlah 16 anak didik yang terdiri atas 8 orang anak laki-laki dan 8 orang anak perempuan. 
Adapun faktor-faktor yang diteliti dan diamati dalam penelitian ini adalah sebagai berikut:

1. Faktor anak, mengamati aktivitas anak dalam proses kegiatan belajar didalam kelas, dalam upaya meningkatkan kemampuan berbahasa anak dengan metode bercerita

2. Hasil belajar anak, mengamati peningkatan kemampuan hasil belajar anak di bidang berbahasa dengan metode bercerita pada anak kelompok B TK Mekar Indah Kendari.

3. Faktor guru, mengamati dan memperhatikan segala aktivitas guru yang mempersiapkan dan melaksanakan kegiatan pembelajaran bagi anak dalam upaya meningkatkan hasil belajar anak di bidang berbahasa melalui metode bercerita di kelompok B TK Mekar Indah Kendari.

Pengumpulan data dalam penelitian ini dihimpun melalui hasil observasi, dokumentasi dan wawancara. Observasi adalah suatu teknik yang dapat dilakukan guru untuk mendapatkan berbagai informasi atau data tentang peremabangan dan permasalahan anak. Melalui pengamatan, guru dapat mengetahui perkembangan yang terjadi pada anak dalam kurun waktu tertentu. Observasi dilakukan oleh guru Kelompok B sebagai observer dengan menggunakan lembar observasi. Penggunaan lembar observasi ini untuk melihat proses pelaksanaan pembelajaran yang dilaksanakan oleh guru ketika melakukan kegiatan pengelompokkan benda untuk meningkatkan kemampuan kognitif anak. Dokumentasi yaitu mencari data mengenai hal-hal atau variable yang berupa catatan, transkrip, buku, surat kabar, majalah, prasasti, notulen rapat, lengger, agenda dan sebagainya (Arikunto, 2010: 274). Dokumentasi ini berupa foto guru/peneliti pada saat proses meneliti sebagai bukti dalam melakukan kegiatan penelitian di lapangan. Wawancara adalah suatu tehnik pengumpulan data yang dapat dilakukan guru untuk mendapatkan informasi tentang perkembangan dan permasalahan anak dengan cara melakukan percakapan langsung, baik dengan anak maupun orang tua.

Analisis data merupakan cara yang dilakukan untuk mengetahui keefektifan suatu metode dalam kegiatan pembelajaran (Aqib, 2009:203).

Pengelolaan data dalam penelitian ini disesuaikan dengan teknik penilaian di TK yaitu dengan menggunakan tanda sebagai berikut: Belum Berkembang $(\mathrm{BB})=*$, Mulai Berkembang $(\mathrm{MB})=* *$, Berkembang Sesuai Harapan $=* * *$, Berkembang Sangat Baik $=* * * *$ (Depdiknas, 2004: 26).

Tabel 1. Kategori keberhasilan klasikal

\begin{tabular}{ccc}
\hline Persentase & Kategori & Simbol \\
\hline $95 \%-100 \%$ & $(\mathrm{BSB})$ & $* * *$ \\
\hline $85 \%-94 \%$ & $(\mathrm{BSH})$ & $* * *$ \\
\hline $75 \%-84 \%$ & $(\mathrm{MB})$ & $* *$ \\
\hline$<75 \%$ & $(\mathrm{BB})$ & $*$ \\
\hline
\end{tabular}

Dari segi indikator hasil, tindakan dikatakan berhasil apabila anak didik telah mencapai nilai berkembang sesuai harapan (BSH) dan berkembang sangat baik (BSB) minimal $85 \%$ baik secara individual maupun klasikal.

\section{HASIL DAN PEMBAHASAN}

\section{Tindakan Siklus I}

\section{a). Aktivitas Mengajar Guru Siklus I}

Analisis data hasil observasi mengajar guru sesuai dengan data hasil observasi sebanyak 11 aspek yang diamati. Pada siklus I aktivitas mengajar guru dari 11 aspek yang diamati ada 8 aspek (73\%) yang tercapai diantaranya: (1) guru menjelaskan tema yang akan diajarkan; (2) guru bercerita menggunakan media pembelajaran; (3) guru meminta anak menceritakan kembali isi cerita lingkungan keluarga yang telah diceritakan; (4) guru meminta anak menyebutkan tokoh cerita dari cerita lingkungan keluarga yang telah diceritakan; (5) guru meminta anak menjawab pertanyaan dari cerita lingkungan keluarga yang telah diceritakan; (6) guru meminta anak menceritakan lingkungan keluarganya; (7) guru memantau anak dan memberi bimbingan kepada anak untuk mengerjakan tugas, dan (8) guru memimpin anak berdoa sebelum pulang.

Sedangkan ada 3 aspek (27\%) yang belum tercapai diantaranya: (1) guru membagikan lembar kerja anak; (2) guru meminta anak bertanya tentang tugasnya, dan (3) guru melakukan tanya jawab tentang kegiatan sehari. Untuk lebih jelasnya dapat dilihat pada histogram berikut: 


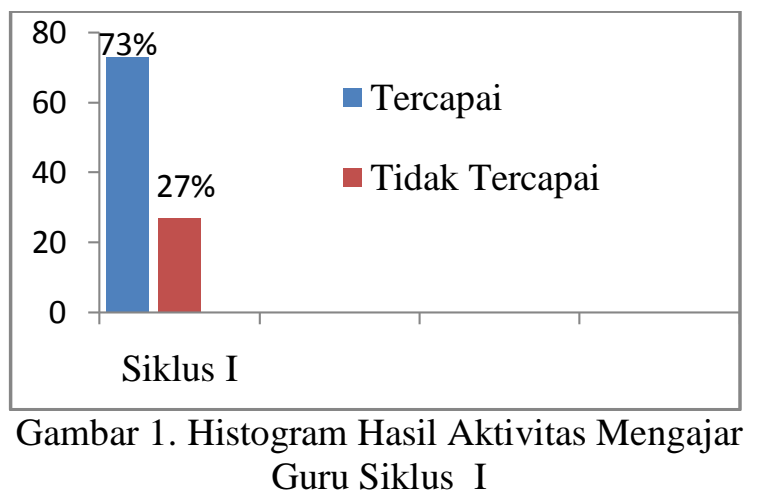

\section{b) Aktivitas Belajar Anak Siklus I}

Analisis data hasil observasi belajar anak sesuai dengan data hasil observasi sebanyak 11 aspek yang diamati. Pada siklus I aktivitas belajar anak dari 11 aspek yang diamati ada 7 aspek (64\%) yang tercapai diantaranya: (1) anak mengetahui tema yang akan diajarkan; (2) anak menceritakan kembali isi cerita lingkungan keluarga yang telah diceritakan; (3) anak menyebutkan tokoh cerita dari cerita lingkungan keluarga yang telah diceritakan; (4) anak menjawab pertanyaan dari cerita lingkungan keluarga yang telah diceritakan; (5) anak menceritakan lingkungan keluarganya; (6) anak mengerjakan tugas; dan (7) anak berdoa.

Sebelum pulang, sedangkan ada 4 aspek (36\%) yang belum tercapai diantaranya: (1) anak mendengarkan cerita secara tenang; (2) anak mengambil lembar kerjanya secara tertib; (3) anak bertanya tentang tugasnya, dan (4) anak menjawab tentang kegiatan sehari. Untuk lebih jelasnya dapat dilihat pada histogram berikut:

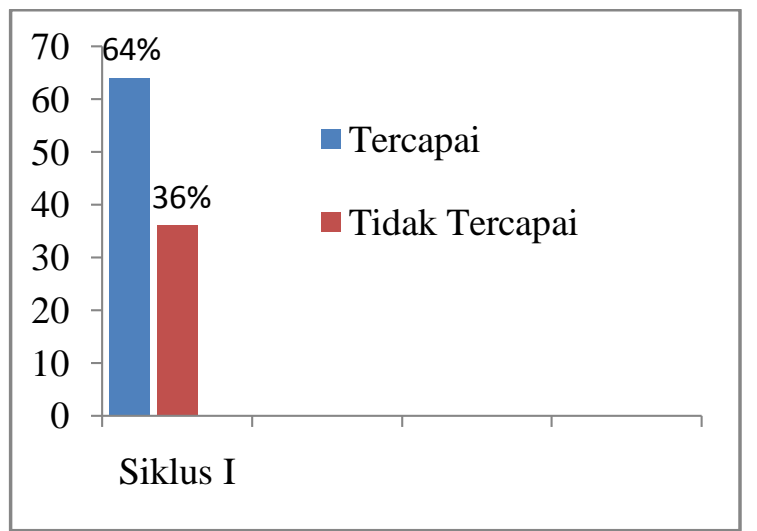

Gambar 2. Histogram Hasil Aktivitas Belajar Anak Siklus I

Berdasarkan histogram aktivitas mengajar guru dan aktivitas belajar anak menunjukkan bahwa hasil aktivitas mengajar guru pada siklus I selama tiga kali pertemuan mencapai $73 \%$ (27\%) belum tercapai), sedangkan hasil aktivitas belajar anak pada siklus I selama tiga kali pertemuan mencapai $64 \%$ (36\% belum tercapai). Dengan demikian hasil aktivitas mengajar guru pada siklus I sebesar $73 \%$ dan hasil aktivitas belajar anak pada siklus I sebesar 64\% dikategorikan belum berhasil yang berpatokan pada indikator ketercapaian aktivitas mengajar guru dan aktivitas belajar anak dapat dikatakan berhasil jika mencapai persentase minimal $75 \%$.

Peneliti bekerja sama dengan guru kelompok B melakuakn evaluasi atau penilaian pada akhir siklus I. Evaluasi dilakukan untuk mengetahui kemampuan berbahasa anak setelah menerapkan metode bercerita. Hasil evaluasi perkembangan kemampuan berbahasa anak di kelompok B TK Mekar Indah Kendari 4 anak (Aq, Ji, Ke, dan $\mathrm{Na}$ ) yang memperoleh nilai bintang empat $(* * * *)$ atau Berkembang Sangat Baik (BSB), 5 anak (Af, Al, Nr, Re, dan Sa) yang memperoleh nilai bintang tiga $(* * *)$ atau Berkembang Sesuai Harapan (BSH), 6 anak (An, De, Dwi, Ir, Iz, dan Rf) yang memperoleh nilai bintang dua (**) atau Mulai Berkembang (MB), dan 1 anak (Ra) yang memperoleh nilai bintang satu (*) atau Belum Berkembang (BB).

Berdasarkan hasil pengolahan data, selanjutnya dilakukan analisis keberhasilan secara klasikal dan diperoleh hasil yang dapat dilihat pada tabel berikut:

Tabel 2. Perhitungan Nilai Klasikal pada Siklus I

\begin{tabular}{ccc}
\hline Kategori & $\begin{array}{c}\text { Jumlah } \\
\text { Anak }\end{array}$ & Presentase \\
Berkembang & 1 & $6 \%$ \\
Sangat Baik & & $25 \%$ \\
$\begin{array}{c}\text { Berkembang } \\
\text { Sesuai Harapan }\end{array}$ & 4 & $56 \%$ \\
$\begin{array}{c}\text { Mulai } \\
\text { Berkembang } \\
\text { Belum }\end{array}$ & 9 & $13 \%$ \\
Berkembang \\
Jumlah
\end{tabular}

\section{Tindakan Siklus II}

\section{a). Aktivitas Mengajar Guru Siklus II}

Analisis data hasil observasi mengajar guru sesuai dengan data hasil observasi sebanyak 11 aspek yang diamati. Pada siklus II aktivitas mengajar guru dari 11 aspek yang diamati ada 10 aspek (91\%) yang tercapai diantaranya: (1) guru menjelaskan tema yang akan diajarkan; (2) guru bercerita menggunakan media pembelajaran; (3) guru meminta anak menceritakan kembali isi cerita lingkungan 
keluarga yang telah diceritakan; (4) guru meminta anak menyebutkan tokoh cerita dari cerita lingkungan keluarga yang telah diceritakan; (5) guru meminta anak menjawab pertanyaan dari cerita lingkungan keluarga yang telah diceritakan; (6) guru meminta anak menceritakan lingkungan keluarganya; (7) guru membagikan lembar kerja anak; (8) guru memantau anak dan memberi bimbingan kepada anak untuk mengerjakan tugas, dan (9) guru melakukan tanya jawab tentang kegiatan sehari, dan (10) guru memimpin anak berdoa sebelum pulang.

Sedangkan 1 aspek (9\%) yang belum tercapai yaitu guru meminta anak bertanya tentang tugasnya. Untuk lebih jelasnya dapat dilihat pada histogram berikut:

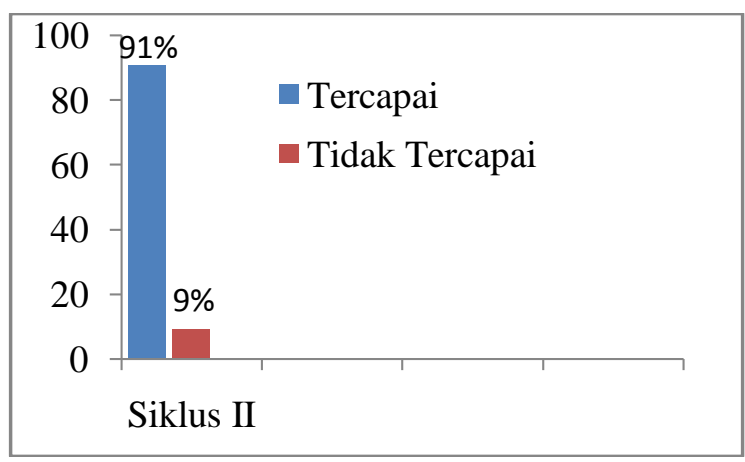

Gambar 3. Histogram Hasil Aktivitas Mengajar Guru Siklus II

\section{b). Aktivitas Belajar Anak Siklus II}

Analisis data hasil observasi belajar anak sesuai dengan data hasil observasi sebanyak 11 aspek yang diamati. Pada siklus II aktivitas belajar anak dari 11 aspek yang diamati ada 9 aspek (82\%) yang tercapai diantaranya: (1) anak mengetahui tema yang akan diajarkan; (2) anak mendengarkan cerita secara tenang; (3) anak menceritakan kembali isi cerita lingkungan keluarga yang telah diceritakan; (4) anak menyebutkan tokoh cerita dari cerita lingkungan keluarga yang telah diceritakan; (5) anak menjawab pertanyaan dari cerita lingkungan keluarga yang telah diceritakan; (6) anak menceritakan lingkungan keluarganya; (7) anak mengerjakan tugas; (8) anak menjawab tentang kegiatan sehari, dan (9) anak berdoa sebelum pulang, sedangkan ada 2 aspek (18\%) yang belum tercapai diantaranya: (1) anak mengambil lembar kerjanya secara tertib, dan (2) anak menjawab tentang kegiatan sehari. Untuk lebih jelasnya dapat dilihat pada histogram berikut:

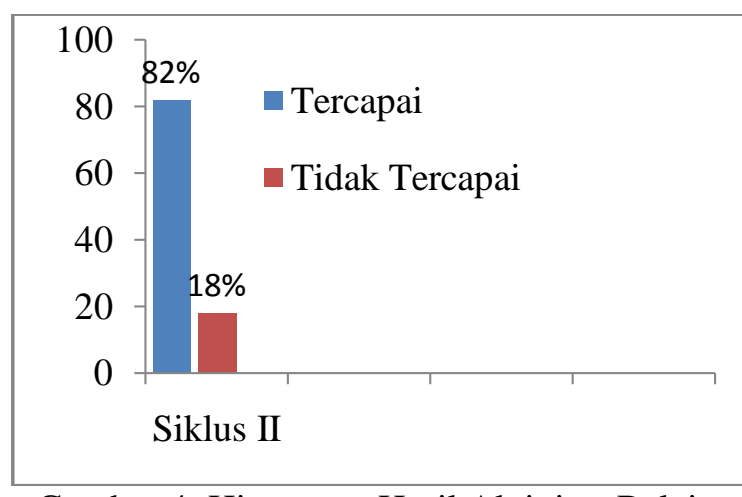

Gambar 4. Histogram Hasil Aktivitas Belajar Anak Siklus II

Peneliti bekerja sama dengan guru kelompok B melakuakn evaluasi atau penilaian pada akhir siklus II. Evaluasi dilakukan untuk mengetahui kemampuan berbahasa anak setelah menerapkan metode bercerita. Hasil evaluasi perkembangan kemampuan berbahasa anak di kelompok B TK Mekar Indah Kendari yaitu 5 anak (Al, Aq, Ji, Ke, dan $\mathrm{Na}$ ) yang memperoleh nilai bintang empat $(* * * *)$ atau Berkembang Sangat Baik (BSB), 9 anak (Af, An, Dwi, Ir, Iz, $\mathrm{Nr}, \mathrm{Rf}, \mathrm{Re}$, dan Sa) yang memperoleh nilai bintang tiga $(* * *)$ atau Berkembang Sesuai Harapan (BSH), 1 anak (De) yang memperoleh nilai bintang dua (**) atau Mulai Berkembang (MB), dan 1 anak ( $\mathrm{Ra}$ ) yang memperoleh nilai bintang satu $(*)$ atau Belum Berkembang (BB).

Berdasarkan hasil pengolahan data tersebut, selanjutnya dilakukan analisis keberhasilan secara klasikal dan diperoleh hasil yang dapat dilihat pada tabel berikut:

Tabel 3. Perhitungan Nilai Klasikal pada Siklus II

\begin{tabular}{|c|c|c|}
\hline Kategori & $\begin{array}{c}\text { Jumlah } \\
\text { Anak }\end{array}$ & Presentase \\
\hline $\begin{array}{c}\text { Berkembang } \\
\text { Sangat Baik }\end{array}$ & 5 & $31 \%$ \\
\hline $\begin{array}{c}\text { Berkembang Sesuai } \\
\text { Harapan }\end{array}$ & 9 & $57 \%$ \\
\hline Mulai Berkembang & 1 & $6 \%$ \\
\hline Belum Berkembang & 1 & $6 \%$ \\
\hline Jumlah & $\mathbf{1 6}$ & $\mathbf{1 0 0 \%}$ \\
\hline
\end{tabular}

Pelaksanaan penelitian ini dilaksanakan dalam dua siklus, dimana tiap siklus terdiri dari 3 kali pertemuan sesuai prosedur penelitian yang telah dirancang sebelumnya. Pada pelaksanaan pembelajaran tiap pertemuan melalui metode bercerita. Setiap pertemuan terdiri atas tiga tahap kegiatan yaitu kegiatan awal, kegiatan inti, dan kegiatan akhir. 
Kegiatan awal, yaitu kegiatan pendahuluan yang dilakukan guru sebelum masuk pada tema pembelajaran, berupa mengucapkan salam, membaca doa, absensi anak serta melakukan gerakan tubuh secara terkoordinasi. Kegiatan inti, yaitu menjelaskan tema pembelajaran, guru menceritakan cerita yang berhubungan dengan lingkungan, guru meminta anak menceritakan kembali isi cerita lingkungan yang telah diceritakan, guru meminta anak menceritakan lingkungannya, guru meminta anak menyebutkan tokoh cerita dari cerita lingkungan yang telah diceritakan, dan guru meminta anak menjawab pertanyaan dari cerita lingkungan yang telah diceritakan. Kegiatan akhir, yaitu guru melakukan tanya jawab tentang kegiatan yang telah dilaksanakan dan membaca doa pulang.

Hasil yang diperoleh terhadap kemampuan berbahasa anak melalui metode bercerita pada observasi awal jika dibandingkan dengan pelaksanaan siklus I terlihat adanya peningkatan, namun belum mencapai indikator kinerja yang diharapkan, sehingga perlu dilaksanakan tindakan siklus II. Hal ini disebabkan pada pelaksanaan tindakan I terdapat beberapa kelemahan guru dalam proses pembelajaran, sehingga perlu dilakukan suatu perbaikan pada perbaikan pada siklus II agat indikator kinerja yang diharapkan dapat tercapai.

Kelemahan guru yang terdapat pada siklus I, yaitu guru belum mampu mengorganisir waktu belajar, sehingga pada tindakan siklus I guru tidak melakukan tanya jawab tentang kegiatan sehari dan guru masih canggung dalam bercerita serta media yang digunakan guru saat bercerita belum menarik perhatian anak untuk mendengarkan cerita guru. Dengan kelemahan guru yang terdapat pada siklus I, sehingga mengakibatkan saat proses pembelajaran sebagian anak didik masih sibuk dengan urusan masing-masing sehingga tidak mendengarkan apa yang disampaikan oleh gurunya, dan sebagian anak didik masih belum memiliki keberanian untuk bercerita di depan teman-temannya.

Berdasarkan hasil refleksi tersebut kemudian dilakukan langkah-langkah perbaikan pada siklus II, yaitu guru sudah mampu mengorganisir waktu belajar, sehingga pada tindakan siklus II guru telah melakukan tanya jawab tentang kegiatan sehari dan guru tidak canggung lagi dalam bercerita dan media gambar yang digunakan guru saat bercerita pada siklus I diganti menjadi media buku cerita bergambar pada siklus II yang membuat anak tertarik untuk mendengarkan cerita. Setelah dilakuakn perbaikan-perbaikan pada siklus II, ternyata hasil yang diperoleh mengalami peningkatan yang cukup signifikan pada aspek kemampuan berbahasa anak. Berdasarkan data yang diperoleh pada siklus I dan siklus II, dapat diketahui perbandingan jumlah anak yang memiliki kemampuan berbahasa dengan kriteria Berkembang Sangat Baik (BSB) dan Berkembang Sesuai Harapan $(\mathrm{BSH})$, sebelum tindakan atau observasi awal sebanyak 5 orang anak didik mendapat nilai Berkembang Sangat Baik (BSB) dan Berkembang Sesuai Harapan (BSH), setelah pelaksanaan siklus I mengalami peningkatan menjadi 9 orang anak didik mendapat nilai Berkembang Sangat Baik (BSB) dan Berkembang Sesuai Harapan (BSH), dan siklus II meningkat lagi menjadi 14 orang anak didik mendapat nilai Berkembang Sangat Baik (BSB) dan Berkembang Sesuai Harapan (BSH), maka dapat dilakukan analisis keberhasilan tindakan secara klasikal dan diperoleh hasil yang dapat dilihat pada histogram berikut:

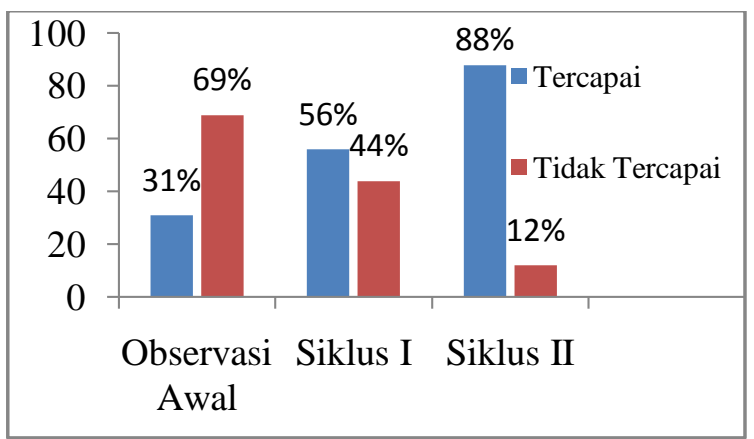

Gambar 5. Rekapan Histogram Hasil Analisis Kemampuan Berbahasa Anak melalui Metode Bercerita

Selama kegiatan penelitian berlangsung, data hasil temuan yang diperoleh sebagaimana dideskripsikan pada halaman sebelumnya, dapat diasumsikan bahwa kegiatan pembelajaran dalam meningkatkan kemampuan berbahasa anak melalui metode bercerita yang dirancang, disusun dan dilaksanakan secara baik dan optimal oleh peneliti yang bekerjasama dengan guru kelompok B pada setiap pertemuan siklus I 
dan siklus II sangat memberikan manfaat pada anak dengan pengalaman langsung, serta kemampuan berbahasa anak menunjukkan peningkatan. Jika dilihat dari pemahaman anak mulai dari pelaksanaan siklus I sebesar 56\% jika dibandingkan pada tahapan observasi awal penelitian yang hanya mencapai persentase $31 \%$ dan pada tindakan siklus II mencapai persentase sebesar $88 \%$, menunjukkan hasil yang lebih baik dari sebelumnya karena indikator kinerja yang ditetapkan telah tercapai yaitu minimal $75 \%$ maka penelitian ini dapat dihentikan.

\section{KESIMPULAN DAN SARAN}

\section{Kesimpulan}

Berdasarkan hasil penelitian yang telah dilakukan selama dua siklus yang masingmasing siklus terdapat 3 kali pertemuan, maka dapat disimpulkan bahwa: Berdasarkan analisis data dari hasil observasi aktivitas hasil mengajar guru pada siklus I diperoleh presentase $73 \%$ (8 aspek yang tercapai dari 11 aspek yang diamati), dan $27 \%$ yang tidak tercapai (3 aspek yang tidak tercapai dari 11 aspek yang diamati). Pada siklus II meningkat menjadi $91 \%$ (10 aspek yang tercapai dari 11 aspek yang diamati), dan 9\% yang tidak tercapai (1 aspek yang tidak tercapai dari 11 aspek yang diamati). Berdasarkan analisis data dari hasil observasi aktivitas belajar anak pada siklus I diperoleh presentase 64\% (7 aspek yang tercapai dari 11 aspek yang diamati), dan 36\% yang tidak tercapai (4 aspek yang tidak tercapai dari 11 aspek yang diamati). Pada siklus II meningkat menjadi $82 \%$ (9 aspek yang tercapai dari 11 aspek yang diamati), dan $18 \%$ yang tidak tercapai (2 aspek yang tidak tercapai dari 11 aspek yang diamati). Berdasarkan hasil observasi yang telah dilakukan pada anak di Kelompok B TK Mekar Indah Kendari pada semester 1 tahun ajaran 2016/2017, menunjukkan bahwa meningkatkan kemampuan berbahasa anak melalui metode bercerita pada observasi awal diperoleh presentase sebesar $31 \%$, dimana terdapat 1 anak yang mendapat nilai Berkembang Sangat Baik (BSB) dan 4 anak yang mendapat nilai Berkembang Sesuai Harapan. Pada siklus I diperoleh presentase sebesar $56 \%$, dimana terdapat 4 anak yang mendapat nilai Berkembang Sangat Baik (BSB) dan 5 anak yang mendapat nilai Berkembang Sesuai Harapan (BSH), dan $44 \%$ yang tidak tercapai, dimana 6 orang anak yang mendapat nilai Mulai Berkembang (MB) dan 1 orang anak yang mendapat nilai Belum Berkembang (BB). Kemudian mengalami peningkatan pada siklus
II sebesar $88 \%$ dimana 5 anak mendapat nilai Berkembang Sangat Baik dan 9 anak mendapat nilai Berkembang Sesuai Harapan (BSH), dan $13 \%$ yang tidak tercapai, dimana 1 anak yang mendapat nilai Belum Berkembang (BB) dan 1 anak yang mendapat nilai Mulai Berkembang (MB).

\section{Saran}

Peneliti menyarankan hal-hal diantaranya: (1) diharapkan kepada guru, dalam pelaksanaan pembelajaran hendaknya mempertimbangkan materi, media, dan strategi yang tepat untuk anak didik dan guru dituntut untuk selalu kreatif dan inovatif dalam melaksanakan kegiatankegiatan yang dapat meningkatkan seluruh aspek perkembangan anak; (2) bagi sekolah, diharapkan dapat menuntut tenaga pendidik menjadi guru yang kreatif, inovatif dalam pengembangan kegiatan-kegiatan pembelajaran untuk anak sesuai dengan tahap perkembangan dan kebutuhan anak.

\section{DAFTAR PUSTAKA}

Arikunto, Suharsimi 2010. Prosedur Penelitian Suatu Pendekatan Praktek. Jakarta: Rineka Cipta.

Bachri, Bachtiar. 2005. Pengembangan Kegiatan Bercerita, Teknik dan Prosedurnya. Jakarta: Depdikbud.

Depdiknas. 2004. Pedoman Penilaian di Taman Kanak-Kanak. Jakarta: Depdiknas.

Dhieni, Nurbiana. 2005. Metode Pengembangan Bahasa. Jakarta : Universitas Terbuka.

Dikdasmen. 2010. Pedoman Pengembangan Program Pembelajaran di Taman Kanak-kanak. Jalarta Kemendiknas.

Ecka, Pramita. 2010. Dahsyatnya Otak Anak Usia Emas, Panduan Pendidikan Orang Tua Dan Guru. Yogyakarta: Perpustakaan Nasional dalam Terbitan Interprebook.

Mansyur. 2007. Pendidikan Anak Usia Dini Dalam Islam. Yogyakarta: Pustaka Pelajar.

Moeslichatoen. 2004. Metode Pengajaran Di Taman Kanak-kanak, Jakarta : PT. Rineka Cipta. 
Ngalimun. 2013. Perkembangan dan Pengembangan Kreativitas. Yogyakarta: Aswaja Pressindo.

Yamin Martinis, \& Jamilah Sabri Sanan. 2013. Panduan Paud Pendidikan Anak Usia Dini. Ciputat : Gaung Persada Press Group. 